\title{
ANALISIS EFEKTIVITAS BIAYA PADA PASIEN GASTRITIS RAWAT INAP DI RUMAH SAKIT BHAYANGKARA MANADO
}

\author{
Amsaline V Hutahaean ${ }^{1)}$, Gayatri Citraningtyas ${ }^{1)}$, Defny S. Wewengkang ${ }^{1)}$ \\ ${ }^{1)}$ Program Studi Farmasi FMIPA UNSRAT Manado, 95115
}

\begin{abstract}
Gastritis is an inflammatory process in the gastric mucosa and submucosa or health problems caused by irritation and infection factors. Treatment therapy used in gastritis is the proton pump inhibitor (PPI), H2 receptor antagonists, and antacids. Giving treatment therapy used by patients has an impact on the amount of medical expenses. The purpose of this study was to determine a more cost effective therapy between the use of omeprazole and lansoprazole in hospitalized gastrtitis patients at Bhayangkara Hospital, Manado. The method used in this study is Cost Effectiveness Analysis with a retrospective data collection on the period of January - December 2018. The sample in this study was 44 patients, consisting of 25 patients using with omeprazole therapy and 19 patients with lansoprazole therapy. The results showed that the most cost-effective PPI was omeprazole with an ACER value of IDR 643,210.37 and ICER value of IDR 631,023.17/ day for each increase in effectiveness if there is a transfer from lansoprazole to omeprazole
\end{abstract}

Keywords: Cost Effectiveness Analysis, Gastritis, Omeprazole, Lansoprazol.

\begin{abstract}
ABSTRAK
Gastritis adalah proses inflamasi pada mukosa dan submukosa lambung atau gangguan kesehatan yang disebabkan oleh faktor iritasi dan infeksi. Terapi pengobatan yang digunakan pada penyakit gastritis yaitu proton pump inhibitor (PPI), antagonis reseptor $\mathrm{H} 2$, serta antasida. Pemberian terapi pengobatan yang digunakan oleh pasien berdampak pada besarnya biaya pengobatan. Tujuan penelitian ini untuk menentukan terapi yang lebih cost effective antara penggunaan omeprazol dan lansoprazol pada pasien gastrtitis rawat inap di RS Bhayangkaara Manado. Metode yang digunakan pada penelitian ini adalah Cost-Effectiveness Analysis dengan rancangan pengambilan data secara retrospektif pada periode Januari - Desember 2018. Sampel pada penelitian ini sebanyak 44 pasien, terdiri dari 25 pasien pengguna terapi omeprazol dan 19 pasien pengguna terapi lansoprazol. Hasil penelitian menunjukkan terapi PPI yang lebih cost-effective adalah omeprazol dengan nilai ACER sebesar Rp. 643.210,37 dan nilai ICER sebesar Rp. 631.023,17/hari untuk setiap peningkatan efektivitas jika akan dilakukan perpindahan dari lansoprazol ke omeprazol.
\end{abstract}

Kata Kunci : Analisis Efektivitas Biaya, Gastritis, Omeprazol, Lansoprazol. 


\section{PENDAHULUAN}

Masalah kesehatan yang dihadapi di negara berkembang saat ini antara lain gastritis, diare, konstipasi dan sebagainya. Prevalensi gastritis di Indonesia mencapai $40,8 \%$, dan angka kejadian gastritis di beberapa daerah di Indonesia cukup tinggi dengan 274.396 kasus dari 238.452.952 jiwa penduduk (WHO, 2012). Kemenkes RI (2013) menyatakan bahwa kasus gastritis pada pasien laki-laki 34.981 dan pasien wanita 53.618. Di Kota Manado tercatat pada tahun 2015 penyakit gastritis menempati urutan ke-4 dengan jumlah 9.074 jiwa (Depkes, 2015).

Terapi pengobatan yang digunakan pada penyakit gastritits yaitu proton pump inhibitor (PPI), antagonis reseptor $\mathrm{H} 2$, serta antasida (Kahrilas,2008). Hasil survei di RS Bhayangkara, salah satu terapi yang digunakan untuk pengobatan gastritis yaitu golongan PPI omeprazol dan lansoprazol. Pemberian terapi pengobatan yang digunakan oleh pasien berdampak pada besarnya biaya pengobatan. Biaya pengobatan yang dikeluarkan semakin meningkat karena pasien juga mengeluarkan anggaran untuk biaya medik langung yaitu biaya perawatan, biaya pengobatan, dan biaya laboratorium.

Kajian farmakoekonomi dilakukan untuk mengidentifikasi obat yang menawarkan efektivitas lebih tinggi dengan harga lebih rendah sehingga dapat dijadikan rekomendasi terapi (Depkes, 2013). Metodologi yang dapat digunakan dalam pengambilan keputusan dalam memilih rekomendasi terapi dilihat dari segi manfaat dan biaya adalah Analisis Efektivitas Biaya (Cost Effectiveness Analysis). Analisis Efektivitas Biaya merupakan salah satu cara untuk menilai dan memilih program terbaik bila terdapat beberapa program berbeda dengan tujuan yang sama untuk dipilih (Trisna, 2007).

\section{METODOLOGI PENELITIAN}

Tempat dan Waktu Penelitian

Penelitian ini dilakukan di Rumah Sakit Bhayangkara Manado pada bulan Desember 2018 - Maret 2019.

\section{Jenis dan Rancangan Penelitian}

Jenis dan rancangan penelitian yang digunakan ialah penelitian deskriptif dengan pengambilan data secara retrospektif yang membandingkan direct medical cost (biaya medis langsung) dari obat Omeprazole atau Lansoprazol pada pasien gastritis rawat inap di RS Bhayangkara.

\section{Populasi dan Sampel}

Populasi dalam penelitian ini ialah seluruh pasien gastritis rawat inap yang menggunakan obat Omeprazol atau Lansoprazol di RS Bhayangkara. Sampel dalam penelitian ini yaitu pasien rawat inap dengan diagnosa gastritis di RS Bhayangkara periode Januari- Desember 2018. Sampel harus memenuhi kriteria inklusi dan eksklusi, sebagai berikut:

Kriteria Inklusi :

1. Pasien gastritis dengan usia $\geq 18$.

2. Pasien gastritis yang mendapatkan terapi omeprazol atau lansoprazol.

Kriteria Ekslusi :

1. Pasien gastritis yang meninggal atau/ dengan penyakit penyerta dan pulang paksa.

2. Pasien gastritis dengan catatan medik tidak lengkap, tidak terbaca dan hilang.

\section{Analisis Data}

Data dianalisis secara deskriptif dan diuraikan dalam bentuk tabel. Setelah data terkumpul, dilakukan perhitungan biaya medik langsung (biaya pengobatan gastritis, biaya perawatan dan biaya laboratorium) pada tiap pasien. Kemudian dijumlahkan masing-masing sesuai penggunaan obat lalu dibuat rata-ratanya. 
Data ini dapat digunakan untuk menghitung rata-rata atau $A C E R$ dengan rumus sebagai berikut (Andayani,2013) :

$$
A C E R=\frac{\text { Biaya }}{\text { Efektivitas }}
$$

Keterangan:

$$
\begin{aligned}
& \text { Biaya } \\
& \text { Efektivitas } \\
& \text { obat }
\end{aligned}
$$

Hasil dari Analisis Efeketivitas Biaya dapat disimpulkan dengan ICER (Incremental Cost-Effectiveness Ratio) seperti rumus dibawah ini :

$I C E R=\frac{\Delta \text { Biaya }}{\Delta \text { Efektivitas }}=\frac{\text { Biaya } A-\text { Biaya } B}{\text { Efektivitas } A-\text { Efektivitas } B}$

Keterangan :

$\begin{array}{ll}\text { Biaya A } & \text { : Biaya teknologi baru } \\ \text { Biaya B } & \text { : Biaya Pembanding } \\ \text { Efek A } & \text { : Efek teknologi baru } \\ \text { Efek B } & \text { : Efek Pembanding }\end{array}$

\section{HASIL DAN PEMBAHASAN}

\section{Angka Kejadian Gastritis}

Seluruh pasien gastritis yang dirawat inap selama periode Januari Desember 2018 berjumlah 625 pasien, jumlah pasien di Ruang Edelweis sebanyak 422 pasien (68\%) dan sebanyak 44 pasien yang memenuhi kriteria inklusi. Berdasarkan sampel tersebut, diperoleh hasil data karakteristik pasien gastritis yang menerima obat omeprazol dan lansoprazol sebagai berikut.

Tabel 1, diperoleh hasil data usia pasien gastritis yang paling banyak ialah kelompok usia 18-25 tahun sebanyak 19 pasien (43\%), diikuti umur 26-35 tahun sebanyak 15 pasien (34\%), selanjutnya usia 36-45 sebanyak 7 pasien (16\%), dan usia 55-65 sebanyak 2 pasien (4\%) serta usia 46-55 tahun sebanyak 1 pasien (2\%). Pada usia tersebut merupakan usia dengan berbagai kesibukan karena pekerjaan dan kegiatan-kegiatan lainnya, sehingga lebih cenderung untuk terpapar faktor-faktor yang dapat meningkatkan resiko untuk terkena gastritis, seperti pola makan yang tidak teratur, stres di tempat kerja, kebiasaan merokok, dan pola hidup tidak sehat lainnya akibat berbagai aktivitas dan kesibukan di usia produktif tersebut. (Rahmi, 2012).

Tabel 1. Data Karakteristik berdasarkan umur pasien gastritis di Ruang Edelweis RS Bhayangkara Manado

\begin{tabular}{ccc}
\hline Umur & $\begin{array}{c}\text { Jumlah } \\
\text { Pasien (n) }\end{array}$ & Persentase (\%) \\
\hline $18-25$ & 19 & $43 \%$ \\
\hline $26-35$ & 15 & $34 \%$ \\
\hline $36-45$ & 7 & $16 \%$ \\
\hline $46-55$ & 1 & $2 \%$ \\
\hline $56-65$ & 2 & $4 \%$ \\
\hline Total & $\mathbf{4 4}$ & $\mathbf{1 0 0 \%}$
\end{tabular}

Tabel 2. Data Karakteristik berdasarkan jenis kelamin pasien gastritis di Ruang Edelweis RS Bhayangkara Manado

\begin{tabular}{c|c|c}
\hline Jenis Kelamin & $\begin{array}{c}\text { Jumlah } \\
\text { Pasien }\end{array}$ & $\begin{array}{c}\text { Presentase } \\
(\%)\end{array}$ \\
\hline Laki-laki & 17 & $39 \%$ \\
\hline Perempuan & 27 & $61 \%$ \\
\hline Total & $\mathbf{4 4}$ & $\mathbf{1 0 0 \%}$ \\
\hline
\end{tabular}

Tabel 2, diperoleh data bahwa pasien yang berjenis kelamin perempuan $61 \%$ lebih banyak menderita gastritis dibandingkan pasien berjenis kelamin lakilaki 39\%. Gastritis lebih sering terjadi pada perempuan karena perempuan rentan secara psikologis unfuk mengalami stress. Secara teori psikologis juga disebutkan bahwa perempuan lebih banyak menggunakan perasaran dan emosi sehingga mudah atau rentan untuk mengalami stress psikologis (Gupta, 2008). 
PHARMACON- PROGRAM STUDI FARMASI, FMIPA, UNIVERSITAS SAM RATULANGI, Volume 8 Nomor 4 November 2019

\section{Analisis Efektivitas Biaya}

Perhitungan Biaya Medik Langsung menggunakan Omeprazol

Biaya medik langsung adalah biaya yang terkait langsung dengan perawatan kesehatan (Permenkes RI, 2013). Perhitungan biaya medik langsing terdapat tiga komponen yaitu biaya pengobatan, biaya perawatan dan biaya laboratorium.
Biaya pengobatan meliputi biaya obat dan biaya alat medis yang digunakan, sedangkan biaya perawatan terdiri dari biaya akomodasi Rp. 350.000/hari, biaya visit dokter umum Rp.50.000, biaya visit dokter spesialis Rp. 110.000, biaya tindakan medik dan biaya administrasi $\mathrm{Rp}$. 35.000 .

Tabel 3. Biaya Medik Langsung (Direct medical cost) pasien gastritis yang menggunakan omeprazol di RS Bhayangkara Manado periode Januari-Desember 2018

\begin{tabular}{|c|c|c|c|c|c|}
\hline No & Nama & & Komponen Biaya (Rp) & & Total (Rp) \\
\hline & & $\begin{array}{l}\text { Biaya Pengobatan } \\
\text { (Rp) }\end{array}$ & Biaya Perawatan (Rp) & $\begin{array}{c}\text { Biaya } \\
\text { Laboratorium } \\
(\mathrm{Rp})\end{array}$ & \\
\hline 1 & $\mathrm{OL}$ & 99.262 & 1.752 .000 & 85.000 & 1.936 .262 \\
\hline 2 & MS & 99.263 & 1.752 .000 & 85.000 & 1.936 .263 \\
\hline 3 & IF & 104.963 & 1.752 .000 & 85.000 & 1.941 .963 \\
\hline 4 & VL & 104.963 & 1.752 .000 & 85.000 & 1.941 .963 \\
\hline 5 & $\mathrm{CI}$ & 105.743 & 1.752 .000 & 85.000 & 1.942 .743 \\
\hline 6 & $\mathrm{RP}$ & 106.803 & 1.752 .000 & 85.000 & 1.943 .803 \\
\hline 7 & IT & 106.803 & 1.752 .000 & 85.000 & 1.943 .803 \\
\hline 8 & GW & 106.803 & 1.752 .000 & 85.000 & 1.943 .803 \\
\hline 9 & $\mathrm{CM}$ & 106.803 & 1.752 .000 & 85.000 & 1.943 .803 \\
\hline 10 & FI & 106.803 & 1.752 .000 & 85.000 & 1.943 .803 \\
\hline 11 & EL & 106.803 & 1.752 .000 & 85.000 & 1.943 .803 \\
\hline 12 & $\mathrm{CK}$ & 106.803 & 1.752 .000 & 85.000 & 1.943 .803 \\
\hline 13 & LL & 106.803 & 1.752 .000 & 85.000 & 1.943 .803 \\
\hline 14 & $\mathrm{NH}$ & 106.803 & 1.752 .000 & 85.000 & 1.943 .803 \\
\hline 15 & $\mathrm{AJ}$ & 106.803 & 1.752 .000 & 85.000 & 1.943 .803 \\
\hline 16 & $\mathrm{CR}$ & 112.503 & 1.752 .000 & 85.000 & 1.949 .503 \\
\hline 17 & SK & 121.993 & 2.338 .000 & 85.000 & 2.544 .993 \\
\hline 18 & DR & 129.533 & 2.338 .000 & 85.000 & 2.552 .533 \\
\hline 19 & RM & 129.533 & 2.338 .000 & 85.000 & 2.552 .533 \\
\hline 20 & AW & 130.133 & 2.338 .000 & 85.000 & 2.553 .133 \\
\hline 21 & DY & 130.313 & 2.338 .000 & 85.000 & 2.553 .313 \\
\hline
\end{tabular}


PHARMACON- PROGRAM STUDI FARMASI, FMIPA, UNIVERSITAS SAM RATULANGI,

Volume 8 Nomor 4 November 2019

\begin{tabular}{cccccc}
\hline $\mathbf{2 2}$ & NH & 135.233 & 2.338 .000 & 85.000 & 2.558 .233 \\
\hline $\mathbf{2 3}$ & KK & 166.993 & 2.338 .000 & 85.000 & 2.589 .993 \\
\hline $\mathbf{2 4}$ & HM & 149.117 & 2.921 .000 & 85.000 & 3.155 .117 \\
\hline $\mathbf{2 5}$ & RM & 163.517 & 2.921 .000 & 85.000 & 3.169 .517
\end{tabular}

Total Direct Medical Cost

55.316 .092

Direct medical cost per pasien

$2.212 .643,68$

Tabel 4. Biaya Medik Langsung (Direct medical cost) pasien gastritis yang menggunakan Lansoprazol di RS Bhayangkara Manado periode Januari-Desember 2018

\begin{tabular}{|c|c|c|c|c|c|}
\hline No & Nama & & $\begin{array}{c}\text { Komponen Biaya } \\
\text { (Rp) }\end{array}$ & & Total (Rp) \\
\hline & & $\begin{array}{c}\text { Biaya Pengobatan } \\
\text { (Rp) }\end{array}$ & Biaya Perawatan $(\mathrm{Rp})$ & $\begin{array}{c}\text { Biaya } \\
\text { Laboratorium } \\
(\mathrm{Rp})\end{array}$ & \\
\hline 1 & SB & 117.568 & 2.338 .000 & 85.000 & 2.540 .568 \\
\hline 2 & $\mathrm{AM}$ & 132.828 & 2.338 .000 & 85.000 & 2.555 .828 \\
\hline 3 & KP & 138.808 & 2.338 .000 & 85.000 & 2.561 .808 \\
\hline 4 & AA & 183.668 & 2.338 .000 & 85.000 & 2.606 .668 \\
\hline 5 & NT & 185.048 & 2.338 .000 & 85.000 & 2.608 .048 \\
\hline 6 & $\mathrm{DH}$ & 148.668 & 2.921 .000 & 85.000 & 3.154 .668 \\
\hline 7 & OR & 156.208 & 2.921 .000 & 85.000 & 3.162 .208 \\
\hline 8 & RA & 156.208 & 2.921 .000 & 85.000 & 3.162 .208 \\
\hline 9 & NW & 156.488 & 2.921 .000 & 85.000 & 3.162 .488 \\
\hline 10 & DG & 160.202 & 2.921 .000 & 85.000 & 3.166 .202 \\
\hline 11 & MS & 162.188 & 2.921 .000 & 85.000 & 3.168 .188 \\
\hline 12 & $\mathrm{JL}$ & 163.748 & 2.921 .000 & 85.000 & 3.169 .748 \\
\hline 13 & TR & 171.882 & 2.921 .000 & 85.000 & 3.177 .882 \\
\hline 14 & LS & 177.268 & 2.921 .000 & 85.000 & 3.183 .268 \\
\hline 15 & CR & 186.962 & 2.921.000 & 85.000 & 3.192 .962 \\
\hline 16 & MS & 208.888 & 2.921 .000 & 85.000 & 3.214 .888 \\
\hline 17 & MK & 220.828 & 2.921.000 & 85.000 & 3.226 .828 \\
\hline
\end{tabular}


PHARMACON-PROGRAM STUDI FARMASI, FMIPA, UNIVERSITAS SAM RATULANGI, Volume 8 Nomor 4 November 2019

\begin{tabular}{ccrccc}
\hline 18 & RP & 237.382 & 2.921 .000 & 85.000 & 3.243 .382 \\
\hline 19 & MB & 242.768 & 2.921 .000 & 85.000 & 3.248 .768 \\
\hline & & & & 57.506 .608 \\
\hline & Total Direct Medical Cost & & $3.026 .663,57$
\end{tabular}

Tabel 4 menunjukkan total biaya medik langsung dengan biaya terbesar yaitu Rp. 3.248.768 dan total biaya medik langsung terkecil yaitu Rp. 2.540.568. Total direct medical cost penggunaan lansoprazol ke-19 pasien yaitu sebesar Rp. 57.506.608 dengan direct medical cost per pasien yaitu Rp. 3.026.663,57.

\section{Perhitungan Efektivitas Biaya Berdasarkan ACER}

Tabel 5. Perhitungan ACER penggunaan omeprazol atau lansoprazol pada pasien gastritis di RS Bhayangkara Manado.

\begin{tabular}{lccc}
\hline Obat PPI & Rata-rata direct medical cost $\mathbf{C}$ ) & Efektivitas (E) & ACER ( C/E) \\
& $(\mathbf{R p})$ & $($ hari) & \\
\hline Omeprazol & $2.212 .643,68$ & 3,44 & $643.210,37$ \\
\hline Lansoprazol & $3.026 .663,579$ & 4,73 & $639.886,59$ \\
\hline
\end{tabular}

Tabel 5 menunjukkan hasil lama perawatan pasien yang menggunakan omeprazol lebih singkat dibandingkan dengan pasien yang menggunakan lansoprazol. Nilai ACER menggambarkan bahwa dengan rasio biaya pengobatan per pasien dibanding dengan efektivitas pengobatan yang didapatkan menunjukkan lebih efektif dan efisien pengobatan yang diberikan (Hidayatullah, 2011).

Nilai ACER adalah biaya yang dikelurakan pasien per hari selama perawatan. Alternatif terapi yang dikatakan lebih cost-effective adalah alternatif terapi dengan nilai rata-rata direct medical cost paling rendah, sehingga dapat disimpulkan bahwa omeprazol lebih cost-effective dibandingkan lansoprazol untuk terapi gastritis rawat inap di RS Bhayangkara Manado.

\section{Perhitungan Efektivitas Biaya Berdasarkan ICER}

Tabel 6. Perhitungan ICER penggunaan omeprazol dan lansoprazol pada pasien gastritis di RS Bhayangkara Mnado

\begin{tabular}{ccc}
\hline $\boldsymbol{\Delta C}$ & $\boldsymbol{\Delta E}$ & $\begin{array}{c}\boldsymbol{I C E R} \\
(\boldsymbol{\Delta C} / \mathbf{\Delta E})\end{array}$ \\
\hline $3.026 .663,579-$ & $4,7-3,44=$ & $631.023,17$ \\
$2.212 .643,68=$ & & \\
\hline $814.019,899$ & 1,29 & \\
\hline
\end{tabular}

Tabel 6 menunjukkan nilai ICER yang diperoleh yaitu $\mathrm{Rp}$ 631.023,17 / hari. Nilai ICER yang diperoleh merupakan besarnya biaya tambahan yang diperlukan untuk memperoleh 1hari pengurangan lama rawat inap pada pasien gastritis. 
PHARMACON- PROGRAM STUDI FARMASI, FMIPA, UNIVERSITAS SAM RATULANGI, Volume 8 Nomor 4 November 2019

\section{KESIMPULAN}

Dari hasil penelitian yang dilakukan disimpulkan bahwa penggunaan terapi omeprazol lebih efektif dibandingkan lansoprazol dengan nilai ACER Rp. 643.210,37. Maka jika pasien gastritis akan berpindah pengobatan dari lansoprazol ke omeprazol perlu menambahkan biaya sebesar nilai ICER yaitu Rp639.886,59/hari.

\section{SARAN}

Penelitian selanjutnya diharapkan dapat melakukan penelitian secara prospektif dengan melihat keadaan pasien selama dirawat di rumah sakit sehingga dapat dihitung efektivitas biaya yang sesungguhnya dikeluarkan oleh pasien.

\section{DAFTAR PUSTAKA}

Depkes RI. 2013. Badan Penelitian dan pengembangan Kesehatan

Kementrian Kesehatan RI. Riset Kesehatan Dasar, Jakarta

Depkes RI. 2015. Profil Kesehatan Sulawesi Utara. Riset Kesehatan Dasar, Manado

Gupta. 2008. Role of oxidative stress in female reproduction. Biomed Cental.

Hidayatullah S. 2011. Pengaruh Status Gizi Terhadap Rawat Inap Anak Rsud Tangerang. FKUI, Jakarta

Kahrilas P. 2006. The Montreal definition and classification of gastroesophageal reflux disease, Global Consensus Group.

Kementrian Kesehatan RI. 2013. Profil Kesehan Indonesia. Kementrian Kesehatan, Jakarta

Permenkes RI. 2013. Peraturan Menteri Kesehatan RI Nomor 69 Tahun 2013 tentang Standar Tarif Pelayanan Kesehatan Pada Fasilitas Kesehatan Tingkat Pertama dan Fasilitas Tingkat Lanjut Dalam Penyelenggaraan
Jaminan Kesehatan. Riset Kesehatan Dasar. Jakarta

Rahmi. 2012. Faktor - Faktor yang Berhubungan dengan KejadianGastritis pada Pasien yang Berobat $\backslash$ Jalan di Puskesmas Gulai Boncah Kota Bukit Tinggi Tahun 2011, Medan

Trisna. 2007. Aplikasi Farmakoekonomi Dalam Pelayanan Kesehatan, Media Informasi Indonesia, Jakarta

World Health Organization. 2012. Angka Kejadian Penyakit. WHO, Amerika 